\title{
Reinvigorating Life of Southern Italy Fortified Architecture in Ruin: From Knowledge to Conservation
}

\author{
By Federica Ribera ${ }^{*} \&$ Pasquale Cucco ${ }^{\dagger}$
}

\begin{abstract}
Southern Italy, the ancient Kingdom of Naples and Sicily, shows a rich heritage of fortified architecture, with towers, castles, boundary walls and any other defensive works, witnesses of historical seasons of sieges and enemy attacks. Over time, with the loss of their original function, many of them, in an advanced state of degradation and abandonment, survive only as ruin, tangible historical trace of ancient architectural artefacts. The ruin is the past that becomes present, by integrating with what now exists; at the same time, it arouses nostalgic and melancholic emotions. Through the ruin it is possible to appreciate particular constructive registers, some distribution systems, materials and any other element useful for technologically and historically reconstructing analysis. The ruins are the result of the "non-academic" skills of the local population. The aim of the research is to evaluate the state of the art of the fortifications in a well-defined geographical area, the Cilento coast, according to the so-called degree of ruderization which allows the restorer to objectively evaluate the state of conservation of the historical buildings and to orientate all the conservative and integrative interventions.
\end{abstract}

\section{Introduction: The Poetic of Ruin}

The fascination of the ruins had over time an ever-increasing attraction, fuelled by travels, archaeological discoveries and works by painters and engravers who have spread the knowledge of ancient monuments all around the Europe. This new passion has its irradiation centre in Rome, where an art market strongly influenced by the fashion of the Grand Tour $^{1}$ polarized the attention on the ancient remains, considered no longer as just elements in the urban landscape but as autonomous subjects with high evocative potential. The ruin, with its nostalgic and creative power, approaches a past with an emotional force that cannot be found in the finished buildings; through it, the past becomes present, actualized, integrated with what now exists. ${ }^{2}$ Therefore, it does not represent only what has disappeared or lost, but through the ruin it is possible to grasp the presence of the past, the sedimentation of age, the grafting of today on a multitude of yesterday.

Already in the XVII century the landscapes paintings by Lorraine, Poussin, Dughet and many others inscribed the ruins within a moral reflection; monuments and nature are subordinated to a conception of deeper spiritual balance. However,

\footnotetext{
*Associate Professor, University of Salerno, Italy.

tPhD Student, University of Salerno, Italy.

1. This name indicates the educational journey by the aristocratic younger throughout Europe. The term Tour clarifies how this trip is specified in a 'tour' - with departure and arrival in the same place - which has Italy as a favorite destination.

2. See J. I. Linazasoro, "Rovine," in Ricomporre la Rovina (ed.) A. Ugolini (Roma: Alinea, 2010).
} 
it is from the XVIII century that the ruins are no longer considered as what remains of the original work, but they begin to be considered in their autonomy, offering themselves as a new form, different to the surrounding universe. Testimony of the past time, they are no longer considered only as architectural "fragments" but as autonomous objects with a high evocative, decorative and, finally, historical value. For these reasons, all the products that the history has disseminated in Europe begin to acquire "monumental" quality, despite their nonfiniteness, fragmentation and age.

The fortified works like fortresses, castles and towers, placed in inhabited centres, on the coasts, at the top of hills and mountains, today represent a rich heritage with characteristics of particular fragility for the antiquity of the structures, the difficult conditions of conservation, the often impervious location and the loss of the original function. Most of them is abandoned or in advanced degradation, waiting for works that can keep their historical content and pass it to the future generations as an "active memory". The castles in a state of ruin represent real palimpsests of construction techniques and styles now disappeared, traces of materials in order to understand the evolution over time of the historical artefacts and the surrounding context.

\section{Research Aim}

The aim of the research - in the current phase of historical-architectural investigation - is to evaluate the state of the art of the fortifications in a welldefined geographical area, the Cilento coast, in Southern Italy rich in historicalcultural events that over the centuries have led to the creation of numerous examples. These castles-ruins are evaluated according to the so-called degree of ruderization which allows the restorer to objectively evaluate the state of conservation of the historical buildings and to orientate all the conservative and integrative interventions, in order to identify, for example, new destinations of use and new possibilities for sustainable functionalization.

In conclusion, the results of the application of the indicator to the cases studied are reported and the good practices for the investigation and conservation of the ruins are traced.

\section{The History of Fortified Architecture in Southern Italy}

Southern Italy, the ancient Kingdom of Naples and Sicily, has a rich heritage of fortified architecture, with towers, castles, boundary walls and every other defensive works, evidence of centuries of history and vicissitudes more or less successful. The evolution of the southern fortification is here treated with 
particular reference to the Cilentan area, ${ }^{3}$ rich in fortified castles in a state of ruin (Figure 1).

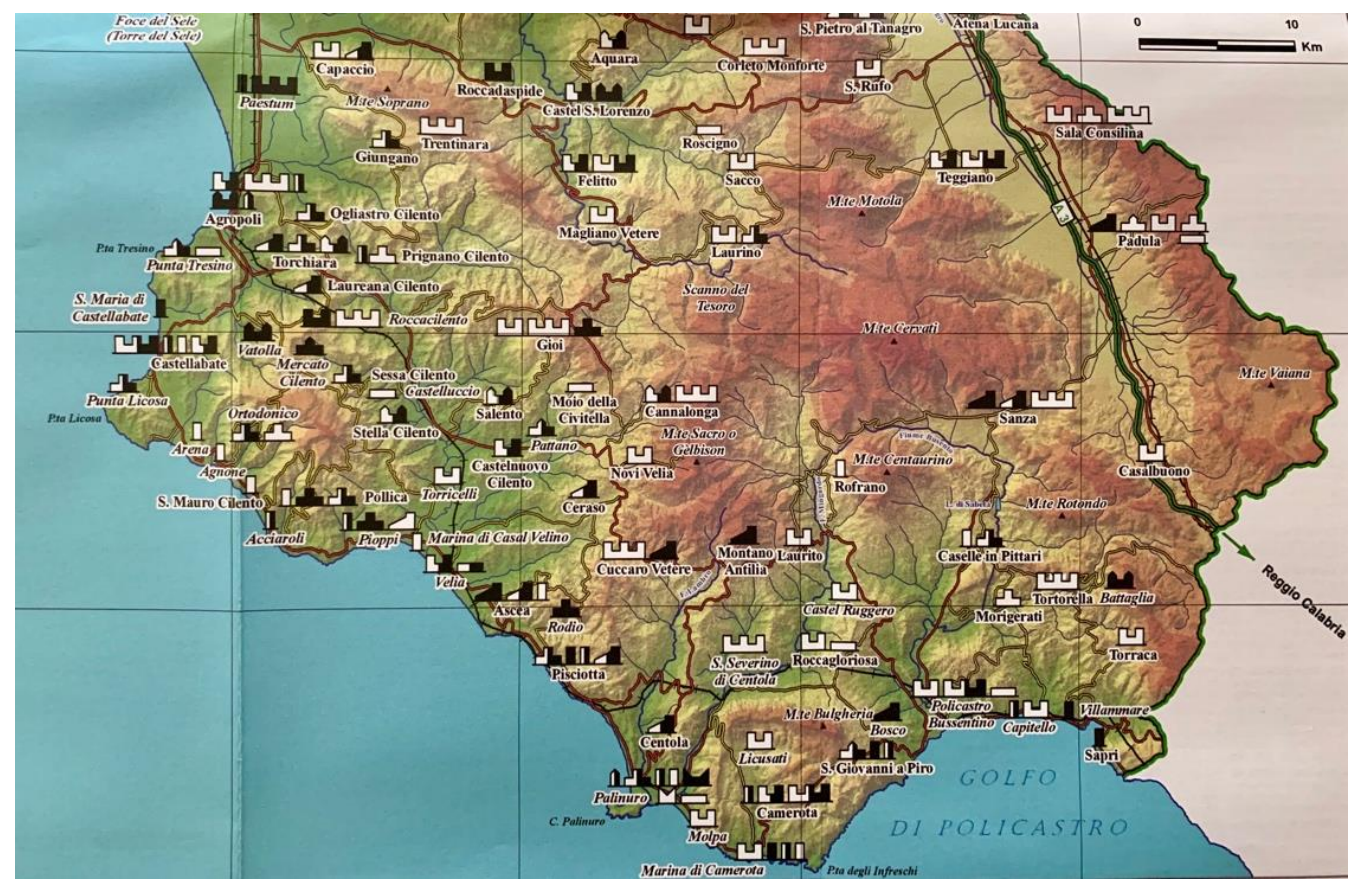

Figure 1. The Cilento Coast in Southern Italy: Location of All the Castles

Source: Istituto Italiano Castelli - Sezione Campania, II ed. 2007.

With the fall of the Western Roman Empire in the V century AD, Italy was exposed to numerous expansionist pressures from northern Europe. ${ }^{4}$ The invading peoples (i.e. Huns and Goths) - had no interest in the construction of urban centres. The first approach to the construction of castles is due to the Byzantines who, after the war against the Goths in 535 A.D., had to protect the maritime areas, easy prey of the enemies. ${ }^{5}$

In the early Middle Ages, Cilento was included in the province "Lucania et Brittiorum," 6 peripheral area of the principality of Salerno, vulnerable to the Saracen attacks. ${ }^{7}$ In Cilento, because of the numerous enemy attacks, the population armed themselves with fortifications, towers, castles, and every other defensive device, built during the Lombard domination (VII-XI century) that, by

3. Cilento is a mountainous sub-region of Campania in the Province of Salerno, in the southern part of the region, declared a UNESCO World Heritage Site. Today it is extended to most of the coastal province of Salerno.

4. See R. Foltz, A. Guillot et al., Origine e Formazione dell'Europa Medievale (Bari: Laterza, 1975), 33-35.

5. See V. Von Falkenhausen, La Dominazione Bizantina nell'Italia Meridionale dal IX all'XI Secolo (Bari: Ecumenica Editrice, 1978).

6. The toponym 'Lucania' appears more frequently in the historical-geographical documentation starting from the second half of the X century and certainly corresponds to Cilento and perhaps to Paestum in particular.

7. See H. Taviani-Carozzi, La Principauté Lombarde de Salerne (Roma: Ecole Française de Rome, 1992), 502-508. 
incorporating the uninhabited internal areas of the territory in the Benevento duchy, led to a repopulation of internal territories with the consequent formation of new residential areas. However, continuous fratricidal struggles between the influential Lombard families of Radelchi and Siconolfo in 849 A.D. led to the creation of two new autonomous states - Salerno and Benevento - event well known with the name of Divisio Ducatus. ${ }^{8}$

In this context, Cilentan territory has been at the centre of many historical events, because of its strategic geographical position near to the sea. This coast is dotted with numerous defence towers and sighting, built on rocky spikes and hills, in order to defend itself mainly from Saracen raids, in virtue of the fact that "Cilento constituted a sort of geographical enclave, an island, in which, apart from the easy maritime access, it was possible the settlement of those who wanted to take advantage of the natural disposition to exert their robberies."9

The first fortifications, rudimentary and private, were built with material from the ancient Greek and Roman factories. These were very irregular artefacts in the planimetric distribution and in the masonry equipment, built without particular technical devices. Nowadays, only a few examples remain, as they are often destroyed and rebuilt in the following seasons. In general, the rich scientific literature is unanimous in recognizing in these early Lombard settlements a prototype of a fortified city: The walls, the tower, a building for the recovery of food supplies, etc. The practice of building ditches, bridges, roads, often winding and inaccessible, is next.

In the Norman age (XII century) was started a process of improvement in the construction of new castles and modernization of the existing ones, with a more organized and technically advanced system. Typical elements of Norman fortified architecture are represented by the appearance of the so-called Donjon, the central defence tower also known as "mastio", and the drawbridges, of which there are only few examples in Cilento.

The next Swabian domination (XIII century), administration tending to centralize the fortified positions in the hands of the central power, gave a new impetus to the construction of castles and towers in this territory. In this way, more complex plans are introduced, as well as the construction of several towers, not perfectly vertical curtains, etc. It should be remembered that in Cilento there are not totally new Swabian settlements, but they are just pre-existing Norman and Lombard fortifications, restored and readjusted. ${ }^{10}$

It will be necessary to wait for the Angevin period (XIII-XV century) to have a renewing action of the feudal society, by starting from the decision to choose Naples as new capital of the kingdom, leaving Palermo in 1266. Not only Naples, but almost all the south of Italy was interested in a powerful renewal action. Great impulse to the construction of fortified systems was done in order to hinder the advance of the Sicilians towards the capital of the Kingdom. The castles of

\footnotetext{
8. See G. Nobile Mattei, "Il Problema della Riqualificazione Giuridica della Divisio Ducatus," Historia et ius 4 (2013).

9. G. Pane, “Architettura, Urbanistica ed Arte,” Il Cilento. Tesoro della Campania 1 (1992): 38.

10. Frederick II of Swabia promulgates a list of castles to be restored and maintained throughout the kingdom; in Cilento only the castles of Policastro, Laurino and Capaccio appear.
} 
Castellabate, Castelcivita, Padula and Castelnuovo Cilento belong to this historic season. In them it is possible to appreciate the evolution of construction techniques, certainly of French inspiration: Cylindrical towers with a truncated conical base, stairs inserted in the thickness of the wall, defence trenches, etc. Under the Angevin domination, the existing fortifications were reconstructed, by inevitably modifying the original face, with the consequence that many XIII century structures were incorporated in constructions different from the original system.

During the Aragonese age (XV century), numerous castles were modified according to the renewed needs; there were more regular planimetric layouts with powerful walls protected by bastions. ${ }^{11}$ In particular, the new features introduced were the lowering of the curtains and towers, the increasing in the wall thickness, the introduction of large "merlons", new and better performing defence devices. ${ }^{12}$

With the fall of the previous domination and the establishment of the Spanish Viceroy (XVI-XVIII centuries), the situation in southern Italy changed considerably: All the administrative power was concentrated in Naples, leaving aside the more remote fiefdoms, which, over time, were turned into country houses. This, obviously, has led to an alteration of the architectural conformation of the artefacts, with the opening of new windows, more modern decorations and elements, etc. It is thanks to the work by Don Pedro of Toledo, urbanist viceroy, the implementation of a vast program of strengthening the whole kingdom, with a modernization of buildings and infrastructures. In this period, the frequent enemy attacks, especially by the Turks, forced the viceroy to issue an authoritative disposition for the construction of defensive works in order to enhance the most vulnerable sea cities. Then, the Duke of Alcalà, Don Pedro Alfan de Ribera, expanded the Toledan work, with constant attention to the control of the whole territory. Especially in Cilento, the duke of Ribera ordered the construction of seven coastal towers in 1566, first from Agropoli to Policastro, then until to Sapri. A general commission for the construction of the towers was set up, so that the Kingdom could have precise informations about the coastal state, the existing structures and the possibility of building new ones. ${ }^{13}$ The result was the construction of 93 towers from Salerno to the borders of Calabria. Nowadays, many of the viceroy towers are in a state of ruin; many others used for new functions; others, in small numbers, are in good conditions.

It is useful to summarize the Cilento fortifications according to the chronological stratification shown below (Table 1).

11. See L. Santoro, "Presentazione," in A Guardia del Territorio. Castelli e Opere Fortificate della Valle del Sarno (ed.) F. Cordella (Napoli: Altrastampa, 1998), 7.

12. See F. Russo, La Difesa Costiera nel Regno di Napoli dal XVI al XIX Secolo (Roma: Laterza, 1989).

13. See C. Crova, "La Difesa Costiera in Età Vicereale nel Regno di Napoli. La Torre del Monte di Scauri: Quadro Storico,” Terra Laboris 12 (2014), 8. 
Table 1. Chronological Summary of the Cilento Fortifications

Lombard era
Novi Velia, Capaccio, Laurino, Rocca Cilento, Gioi Cilento, Felitto, Cuccaro Vetere, Agropoli, San Severino di Centola, Stio Cilento, Prignano, Vatolla.

Policastro, Castellabate, Casalbuono

Norman era

Swabian era

(extensions and restorations)

Angevin era

Aragonese era

Viceroy age

(coastal towers)
Policastro, Laurino, Capaccio, Roccadaspide

Castelnuovo Cilento, Castelcivita, Capitello, S. Marina, Padula.

Teggiano, Rocca Cilento, Sessa

Cilento.

Agropoli, Castellabate, Agone, Policastro, Sapri.

\section{Degree of Ruderization}

There are many causes that can lead a monument to the deterioration typical of the state of ruin: Passing time, negligence, tampering, the evolution of economic, cultural and social cycles, the succession of earthquakes, landslides, floods, local wars, the abandonment of original settlements, changes in use, etc. The process of ruderization can be more or less fast and profoundly different may be the outcomes and degenerative pathologies in progress on the artefacts.

The levels of degradation are very different and require planning and intervention modalities studied case by case. For this reason, is being tested a new parametric indicator to support the professionals in the objective evaluation of the state of conservation of the historical artefact and to choose the best conservative and integrative intervention. The indicator is the so-called "Degree of ruderization", that is the percentage ratio of authentic material now conserved and the original state of the whole building. According to it, three levels are identified:

1) Level 1 - total loss of coverage.

2) Level 2 - progressive loss of portions of supporting structures.

3) Level 3 - hard ruderization, over $70 \%$.

Once the roofing has been lost, the degree increases, with the progressive loss of vertical and horizontal structures, until the total loss of the building.

The definition of this parameter can be a valid help in defining the interventions to be carried out on the ruined buildings, operating first on more unfavourable parameters (absence of coverage, infesting vegetation, wall cracks, etc.). In it, many aspects can be merged and changed, added or subtracted, by adapting them, from time to time, to the cases in question. 
By identifying the level of ruderization and the most favourable and unfavourable parameters of a building helps the technician and the decision maker (public administration, protection institutions, individuals, community) in the choice of priority actions to be carried out in the protection of buildings and in making future reflections on the ability to integrate the building with possible reuse and recovery programs, on an architectural, landscape, social and economic level.

It is evident that there are important differences in conservation between a building that become a ruin by following a slow process of aggression by environmental, chemical and physical factors, and one affected by a fast and violent event like a natural disaster or a war event. Studying the fortifications in Cilento, in addition to a historical-geographical characterization, we tried to identify the correct degree of ruderization, albeit with all the random variables that the theme involves.

Below is an analytical model, currently being tested and refined, proposed as a useful support to the restorer in verifying the degree of ruderization of a ruined historical building and, therefore, in defining the potential level of integration within a conservation and re-use project. It is particularly important to deepen the knowledge of the most current approaches to the theme of conservation and sustainable management of ruins, by helping the architect to know how to relate correctly to the project without compromising the heritage authenticity.

This model does not replace the professionalism and experience of scholars but intends to be a valid aid in the analysis of the ruins and in the proposal of optimal interventions, at a global or local level. Therefore, the goodness of the model is guaranteed by a process of continuous validation of experts in the sector, whose judgment (through historical investigation, photographs and inspections on site) is compared each time with that returned by the model.

This model is based on a multiple linear regression rule of the type:

$$
\mathrm{Y}=\mathrm{b}_{0}+\mathrm{b}_{1} \mathrm{X}_{1}+\mathrm{b}_{2} \mathrm{X}_{2}+\ldots+\mathrm{b}_{\mathrm{n}} \mathrm{X}_{\mathrm{n}}+\mathrm{e}
$$

where $Y$ represents the dependent variable, each variable $X_{i}$ indicates the value assigned to a parameter, each coefficient $b_{i}$ represents the weight to be associated to each parameter and $e$ allows to manage a possible estimation error.

The first phase consists of transforming the nominal values of each parameter (predefined classes) into numerical values. The consolidated rules of transformation from class to numerical value are used.

The parameters used in the model are those most frequently encountered in cases of ruined artefacts. They affect the final result to a different extent, so we distinguish 2 categories to which different weights are attributed:

1) High value parameters.

2) Medium-low value parameters. 
All parameters that depend on others already present are excluded, since their presence could introduce noise into the model and, therefore, lower its degree of goodness.

High value parameters have the greatest influence on the degree of ruderization of a building and that are always present.

They are restricted to two main fixed parameters, excluding those in direct dependence (Table 2).

Table 2. High Value Parameters

\begin{tabular}{lc}
\hline Loss of coverage & $\mathbf{X}_{\mathbf{1}}$ \\
\hline Expanded & 1 \\
\hline Media & 0.66 \\
\hline Partial & 0.33 \\
\hline & \\
\hline Loss of vertical structures & $\mathbf{X}_{\mathbf{1}}$ \\
\hline Expanded & 1 \\
\hline Media & 0.66 \\
\hline Partial & 0.33 \\
\hline
\end{tabular}

Low-medium parameters have a minor influence on the degree of ruderization of a building compared to the previous ones. It should be noted that the lowmedium parameters can be chosen at the discretion of the evaluator, considering case by case the artefacts to be ruined.

This possibility involves the definition of a flexible and updatable model based on real circumstances, avoiding rigidity and poor adaptability to always different cases. Only a few of the possible parameters included in this category are proposed below (Table 3).

Table 3. Medium-Low Value Parameters

\begin{tabular}{|lc|}
\hline Integrity of the wall crests & $\mathbf{X}_{\mathbf{1}}$ \\
\hline Poor & 1 \\
\hline Average & 0.66 \\
\hline Good & 0.33 \\
\hline Weed vegetation & $\mathbf{X}_{\mathbf{2}}$ \\
\hline Expanded & 1 \\
\hline Reduced & 0.66 \\
\hline Minimum & 0.33 \\
\hline Past restoration works & $\mathbf{X}_{\mathbf{3}}$ \\
\hline absent & 1 \\
\hline Partial & 0.66 \\
\hline extended & 0.33 \\
\hline
\end{tabular}

The second phase consists in facing is to define the values of the coefficients $b_{0} \ldots b_{n}$. 


\begin{tabular}{lccc}
\hline & Single Coeff. & No. of parameters & Total \\
\hline High parameter & 0.35 & 2 & 0.70 \\
$\begin{array}{l}\text { Medium-low } \\
\text { parameter }\end{array}$ & $\mathrm{X} / \mathrm{n}$ & $0 \mathrm{a} \mathrm{n}$ & 0.30 \\
\hline
\end{tabular}

Once the data have been replaced by the unknowns and the final result obtained in the light of the parameters involved, it is possible to use a simple classification rule that allows to classify the value of the index based on the results previously obtained.

\begin{tabular}{lc}
\hline if $Y<0.35$ & Low - Level 1 \\
\hline if $Y>=0.35$ and $Y<0.70$ & Medium - Level 2 \\
\hline if $Y>=0.70$ & High - Level 3
\end{tabular}

In this research the documentation curated by the "Istituto Italiano Castelli Campania Section" has been a very precious help. It developed an effective "Charter of the Castles" and related symbolism - here reported - was adopted by the Scientific Council of the Institute from 1965. It consists of sixteen typological symbols that identify the various types to which a fortified architecture can belong with particular reference to the state of consistency of the fortification that indicates how much of the original monument survives today (Figure 2).
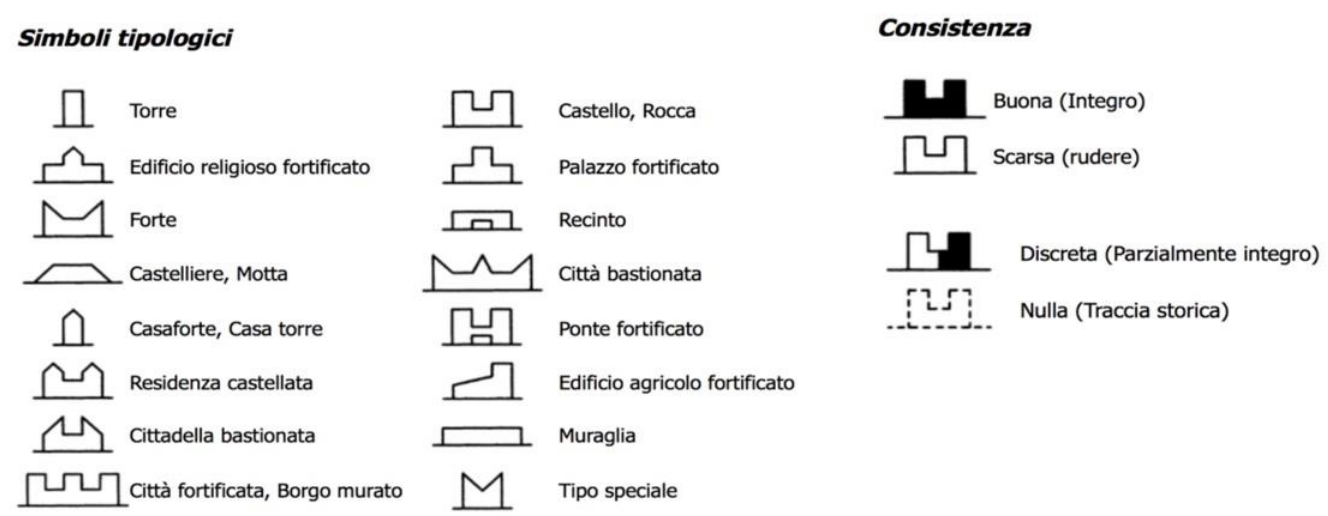

Figure 2. Official Symbols of the Italian Castelli Institute. The Degree of Consistency Refers to how much of the Original Building is Visible Today

Source: Istituto Italiano Castelli - Sezione Campania, II ed. 2007.

That following is the classification of the ruin castles (X-XII centuries) referred to the Cilento area, in chronological order, where it is possible to find the date, the geographic location, the degree of ruderization and brief historical notes. The degree of rudeness is evaluated according to the above proposed model, but the calculations are omitted here.

It is a study of the state of the art about the castles in ruins in a defined temporal interval. The research is still ongoing and aims to provide a complete mapping of all the ruined fortifications even in the following centuries. 


\section{X-XI Centuries}

Laurino. The Castle of Laurino belongs to the X century, located on a hill at $531 \mathrm{mt}$. The structure is still partly legible even if the upper floors are almost all collapsed. The "Castello de lauri" is mentioned for the first time in a document dated 932 AD. Only in 1271 appears the Valdemonte family as the first feudatory of Laurino. At the end of the 16th century it was largely replaced by the majestic ducal palace of the Carafa noble family. Its definitive abandonment is when in 1734 Charles III obliged the various feudal lords to reside in Naples rewarding them with important court positions. Today survive only the ruins in a great spectacular environment. Degree of ruderization: LEVEL 3.

Novi Velia. The Castle of Novi Velia dates back to the XI century, later transformed and fortified by Tommaso Marzano, Duke of Sessa, in 1323, who provided it with powerful towers. At the end of the XIV century the castle was donated by Frederick of Aragon to Berlingiero Carafa, under whose dominion the castle knew its period of maximum splendor. Later it was bought and turned into a noble palace. Today there are still visible majestic remains of the towers, the curtains and the battlements. Degree of ruderization: LEVEL 3 (Figure 3).

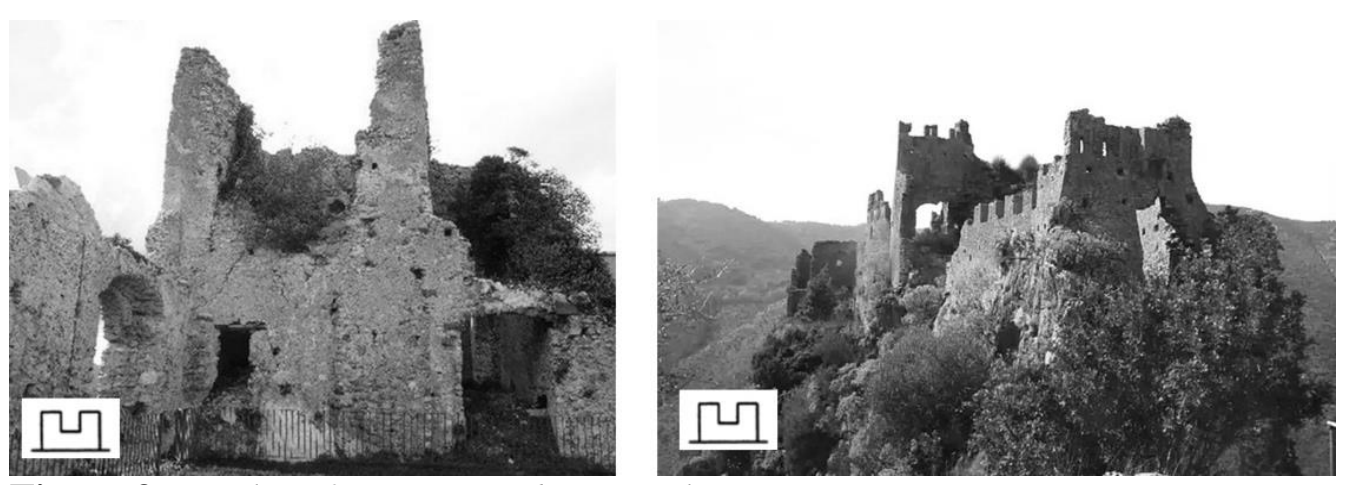

Figure 3. Castles of Laurino and Novi Velia $(\mathrm{Sa})$

\section{Century}

Velia. The characteristics of the fortification of Velia, consisting of a castle and a high cylindrical tower on a truncated conical base, can be found in other fortifications built in the same period (in Castelnuovo Cilento, Castelcivita, Maddaloni and Amalfi). When the military war requirements failed, the tower was used as a private residence for the various wealthy families of the area. The castle of Velia today represents a very rare or perhaps the only example of a medieval tower inserted in a Greco-Roman context. Since 1994, the Salerno Superintendent of the Archaeological Heritage, in order to ensure the conservation of the tower, has undertaken the restoration of the outer walls of the ridges. The defensive system of Velia, in the territory of Ascea Marina, between the cities of Agropoli and Palinuro, was built to defend itself from the barbarian invasions, using the material coming from the ancient factories of Greek and Roman origin. The Tower, from the Angevin period, dates back to the XIII century and soon became an integral part of the castle, rebuilt in the Norman period and then destroyed by 
Frederick II. Only the ruins remain on the edge of the promontory, a cylindrical turret and a sheer cliff. Degree of ruderization: LEVEL 3.

Camerota. The small town of Camerota is divided into a historical center made up of narrow streets, covered with arches, and originally protected by a medieval wall. Of the various access gates to the inhabited area, the only one visible today is Porta di Suso, decorated in the upper part by a marble head of one of the marquises who controlled Camerota in the mid-1100s. The highest part of the village is dominated by the medieval castle. The Marquisal castle of Camerota, consisting of a two-level building, was equipped with a main tower, useful to ensure the defense against enemy attacks. In 1552 a Turkish army attacked the castle and damaged it. Today only the boundary walls, the moat, the towers and a chapel inside remain. The castle, home of the various feudal families that have succeeded over the centuries, is currently open to visitors. Degree of ruderization: LEVEL 3 (Figure 4).
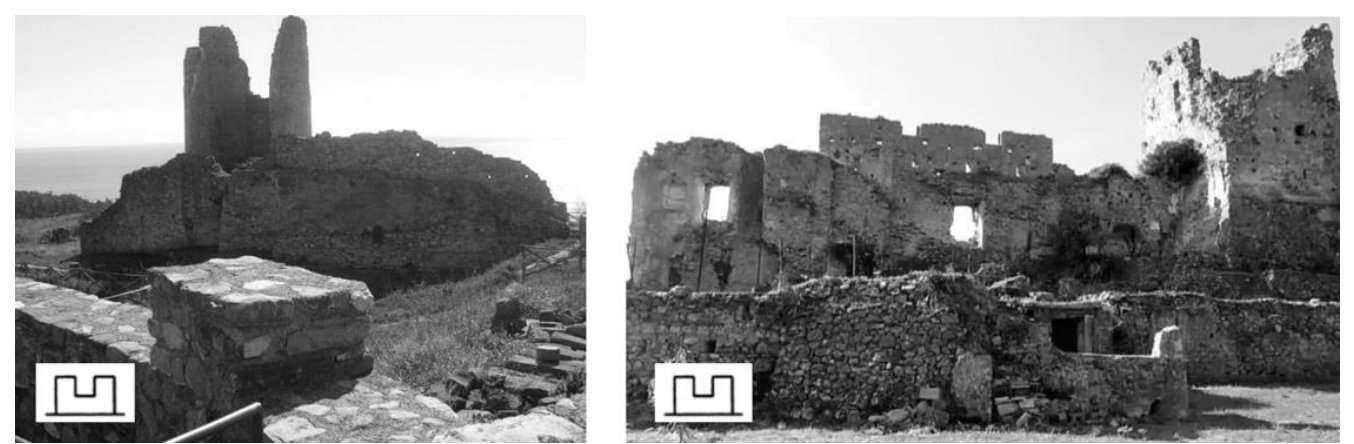

Figure 4. Castles of Velia and Camerota ( $\mathrm{Sa})$

Capaccio. Very little remains of the ancient city walls of the city of the town of Capaccio. Precise data on the evolution of Capaccio Vecchia are provided by the ruins of cisterns and wells. Today, the entire planimetric conformation remains of the medieval urban settlement, which was subject to several levels of development. Traces of beautiful houses found near the top of Mount Calpazio, together with some fragments of ceramics, testify the presence of inhabited nuclei in the ancient village at least until the eighteenth century. The village extended on the northern slope of the hill with the castle placed in defence of the city. The ruins of the castle still dominate the plain. The castle was built to defend the city from the frequent raids of the Saracens; in 1246 it became the protagonist of the event remembered as the "Congiura di Capaccio", against Frederick II of Swabia: The conspirators, who took refuge in the castle, were killed and the fort was conquered after only three months. Then, the castle was renovated during the Angevin and Aragonese period and used as a prison. Disused until the end of XIX century, when it was used by the Military Engineers, now is into a state of complete abandonment. Degree of ruderization: LEVEL 3.

Gioi Cilento. At Gioi Cilento, almost nothing remains of the castle, located on a hill almost $700 \mathrm{mt}$ above sea level, in the middle valley of the Alento. However, traces of the town walls still remain, with cylindrical turrets on the defensive curtain on the north side of its perimeter. The village is still dominated 
by the remains of the ancient castle. «Essendo Gioi, circondata da massicce ed inespugnabili mura, si entrava in paese da sette Porte. Fra settentrione e levante ne esisteva una detta "Portanova". Era di forma architravata, ampia; e dai ruderi e dai diversi pezzi di considerevoli dimensioni, che ancora si conservano, è da credere che "Portanuova" sia stata maestosa, magnifica, ben lavorata e degna veramente, solo di un'Università agiata. Dalla base, su cui erano sdraiati due leoni ed un leoncino, si innalzavano alti, larghi e scanalati pilastri, di pietra compatta e tenace, e terminavano con un architrave, e con cornice finale, ben corrispondente.» ${ }^{14}$ Degree of ruderization: LEVEL 3 (Figure 5).
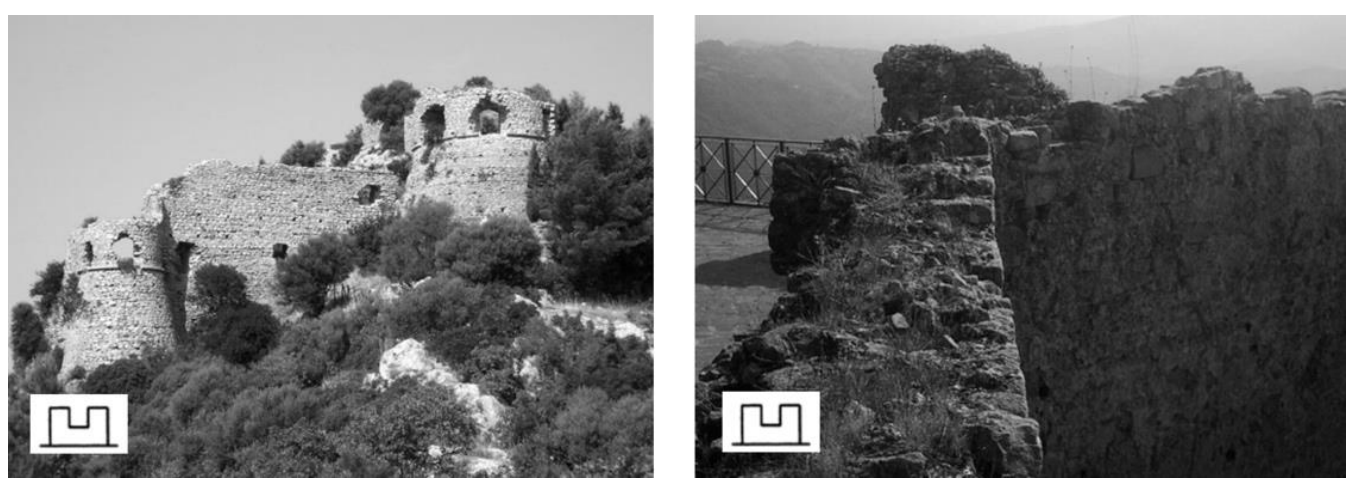

Figure 5. Castles of Capaccio and Gioi Cilento ( $\mathrm{Sa})$

\section{Discussion and Results}

The knowledge project offers valuable information about the nature of buildings and their condition. The model for the definition of the degree of ruderization gives back a good objectivity in the definition of the state of fact of the works and it is useful in the definition of the interventions to be carried out, operating first on the most unfavourable parameters. Moreover, the ability to adapt and modify the parameters, especially the medium-low ones, which can be varied, added or subtracted, adapting from time to time to the cases under examination, is appreciable.

Identifying the level of rudeness and the favourable and unfavourable parameters of an artefact helps the technician and the decision-maker (public administration, protection bodies, private) in the choice of the priority interventions to be carried out in safeguarding the buildings and in making future reflections on the integration capacity of the construction with possible programs of reuse and recovery, at architectural, landscape, social and economic level.

Certainly, the model is open to next implementations and improvements that can affect the classes, the numerical values and the number of classes (extended, average, partial), by following on-site experiences and expert validations.

Future scenarios also include the refinement of the coefficients $b$.

The cases assessed fall within the level 3, advanced ruin, and therefore need priority and urgent interventions for the safety of the walls and to avoid the

14. See G. Manna and A. Salati, L'antica Gioi (Napoli: Edizioni Scientifiche Italiane, 2003). 
disappearance of goods with high material and immaterial value. The research is now moving towards the next phase, which consists of evaluating the levels of integration with the new functions.

The castle-ruin is almost familiar with the landscape in which it is inserted, drawing unusual profiles of hills and mountains. It tells of legends, stories of misery or fortune, destructive events and abandonment, representing an ineliminable element of the identity of the place, so that its loss would arouse in the community a sense of extraneousness and emptiness.

For this reason, any project must take due account of the testimony it bears for the whole territory and civil society, in terms of tangible and intangible signs, marked by the time that, like a "great sculptor", is able to engrave the statues, monuments, beauties in the open air and, by extension, even the entire human race. However, the approaches to safeguarding and managing ruins remain a very open problem, by virtue of searching for balance between the needs of the authenticity protection and the urgencies of the changed contemporary panorama.

The first phase is the "project of knowledge". Once this phase is completed, the expert can make a first critical evaluation by virtue of what has been found and of his own experience.

This evaluation is useful in the subsequent "description phase" in which the building is inspected in its decay and instability factors. In this stage it is useful to use the model for the definition of the degree of ruderization, whose parameters and results may be a valid turning point in the drafting of a more prudent project, by defining the priority of the interventions and the possible level of integration. This second phase ends with a new critical evaluation of the observer aimed at strengthening or, on the contrary, at modifying the first initial estimates.

The next "characterization phase" includes the evaluation of the causes and of the "diseases" that the building suffers from which, together with the previous investigations, allows the implementation of conservation, rehabilitation and consolidation interventions, after a careful diagnostic investigation. The latter is of fundamental importance, especially in the field of archaeological restoration, in order to determine present and future risks and define a project characterized by conservative actions based on the criteria of minimum intervention, noninvasiveness and reversibility.

Finally, it is necessary to envisage post-project activities that can guide towards the best enhancement of the work in the context in which it is located, with a view to global enjoyment by several types of users (overcoming physical architectural barriers or sensory, indoor or outdoor lighting, scheduled maintenance, effective communication of historical and architectural features, dissemination of symbolic and cultural values).

\section{Conclusions}

The castles-ruins represent the testimony of the past but, at the same time, they are dynamic works, available to integrations and new relationships. It is not a question of pure abandoned stones but of a new form and image that, despite its 
fragmentary nature and incompleteness, is absolutely meaningful, full of historical values, like an artistic work to preserve, with the least possible alterations, in order to guarantee its future interpretation. ${ }^{15}$

It is necessary to make a new reflection on the problems related to the recovery and constant maintenance of castles and fortified works, according to new systematic approaches to seismic risk and to the behaviour of masonry structures that require a more careful evaluation of interventions in different aspects: historical-architectonic, security, functionality, potential for fruition in the future. A correct intervention in defence of this important heritage can guarantee the preservation of its aesthetic and historical identity and avoid the introduction of extraneous or invasive elements that can distort the historical-architectural configuration of the building complex. ${ }^{16}$

The lack of knowledge of this particular form of architecture has often led to abandonment, incautious interventions and even demolitions of fortifications and entire city walls. The diffusion of knowledge and culture for the protection can, however, lead to a correct "use" and "fruition" of ruins and fortifications, in order to respect the communities and to pass on the history, tradition and evolution of territories and their identity.

\section{Bibliography}

Crova, C. "La Difesa Costiera in Età Vicereale nel Regno di Napoli. La Torre del Monte di Scauri: Quadro Storico." [Coastal Defense in the Viceroy Age in the Kingdom of Naples. The Tower of Monte di Scauri: Historical Framework.] Terra Laboris 12, no. 8 (2014).

Foltz, R. and A. Guillot et. al. Origine e Formazione dell'Europa Medievale. [Origin and Formation of Medieval Europe.] Bari: Laterza, 1975, 33-35.

Manna, G. and A. Salati. L'Antica Gioi. [The ancient Gioi.] Napoli: Edizioni Scientifiche Italiane, 2003.

Linazasoro, J. I. "Rovine." [Ruins.] In Ricomporre la rovina. Edited by A. Ugolini. Roma: Alinea, 2010.

Nobile Mattei, G. "Il Problema della Riqualificazione Giuridica della "Divisio Ducatus."” [The Problem of Legal Redevelopment of the "Divisio Ducatus."] Historia et ius 4 (2013).

Pane, G. Architettura, Urbanistica ed Arte. Il Cilento. [Architecture, Urban Planning and Art. Cilento.] Napoli: Tesoro della Campania, Napoli, 1992.

Ribera, F. "Presentazione.” [Presentation.] In Testimoni di Storia. L'Architettura Molisana tra Conservazione e Riuso. Edited by P. Cucco. Salerno: Officina Delle 11, 2018.

Russo, F. "La Difesa Costiera nel Regno di Napoli dal XVI al XIX Secolo." [The Coastal Defense in the Kingdom of Naples from the $16^{\text {th }}$ to the $19^{\text {th }}$ Century.] Roma: Laterza, 1989.

Santoro, L. "Presentazione." [Presentation.] In A Guardia del Territorio. Castelli e Opere Fortificate della Valle del Sarno. Edited by F. Cordella. Napoli: Altrastampa, 1998, 7.

15. See P. Torsello, "Il Rudere come Testo e Pretesto," in Proceedings "Il Rudere tra Conservazione e Reintegrazione" (Roma: Gangemi Editore, 2006).

16. See F. Ribera, "Presentazione," in Testimoni di Storia. L'Architettura Molisana tra Conservazione e Riuso (ed.) P. Cucco (Salerno: Officina Delle 11, 2018). 
Taviani-Carozzi, H. La Principauté Lombarde de Salerne. [The Lombardy Principality of Salerno.] Roma: Ecole Française de Rome, 1992, 502-508.

Torsello, P. "Il Rudere come Testo e Pretesto." [Ruin as Text and Pretext.] In Proceedings for "Il Rudere tra Conservazione e Reintegrazione. Roma: Gangemi Editore, 2006.

Von Falkenhausen, V. La Dominazione Bizantina nell'Italia Meridionale dal IX all'XI Secolo. [The Byzantine Domination in Southern Italy from the $9^{\text {th }}$ to the $11^{\text {th }}$ Century.] Bari: Ecumenica Editrice, 1978. 
